\title{
A QUESTAO DO JULGAMENTO DA PESQUISA
}

A despeito de saudáveis discussões concernentes ao caráter epistemológico ou heurístico, e até mesmo das questões hermenêuticas, a palavra "pesquisa" suscita diferentes reações comportamentais. $\hat{E}$ fácil distinguir, entre os assessores das agências financiadoras de pesquisa ou órgãos universitários, aqueles cujas críticas são fundamentadas em expressiva experiência, conhecimento sólido, imparcialidade e compromisso com a ciência. Esses assessores são poucos e constituem a pequena comunidade dos verdadeiros "cientistas". Suas posturas diferem substancialmente daquelas que resultam em pareceres limitados, parciais, cujos autores são comprometidos apenas com sua própria sobrevivência e apadrinhamento ao seu próprio grupo. O valor maior reside na perpetuação do poder caracterizado pelo livre trânsito nos comitês julgadores $e$ uso de prestigio pessoal para garantir que a fatia do bolo não seja repartida, sem falar naqueles que rejeitam a publicação de pesquisas mas aproveitam-se das idéias nelas contidas.

Que tipo de postura, compromisso e ética devem ser esperados daqueles que por deliberação própria aceitam assumir a responsabilidade do julgamento de verbas destinadas ao desenvolvimento científico?

Recentemente muitos pesquisadores foram surpreenciidos pela nova política de priorização da pesquisa no país estabelecido pelo atual governo e por alguns pronunciamentos de líderes da Secrataria de Ciência e Tecnologia. A tendência para aplicação de recursos no desenvolvimento de novas tecnologias visando soluções mais econômicas resultou na preocupação de pesquisadores (e até mesmo de estudantes de pósgraduação) com o enfraquecimento da pesquisa acadêmica e da pesquisa pura. Infelizmente algumas matérias publicadas em jornais públicos talvez possam ter confundido o leitor quanto ao conceito de pesquisa pura e acadêmica, como se a universidade só tivesse o compromisso de desenvolver a pesquisa pura e a pesquisa aplicada e tecnologia de ponta emergisse apenas dos meios extra acadêmicos ou se esses não fossem capazes de realizar a pesquisa pura.

O momento é propício para ser refletido o compromisso pessoal, grupal e institucional necessário ao julgamento da pesquisa e definição de prioridades. Este editorial é uma mensagem aos colegas pesquisadores enfermeiros ou não especialistas na matéria em apreço. Reagir é questão de dignidade pessoal, grupal, institucional. É uma contribuição 
saudável e necessária ao desenvolvimento científico, o qual pode ser retardado apesar dos esforços de pesquisadores atuando em núcleos tradicionais ou emergenciais.

E também preciso meditar sobre nossas posturas e transcender a preferência por metodologias específicas quando na conciição de juízes, analisando à luz da fronteira do conhecimento propiciado pelo esforço de diferentes pesquisadores, grupos, instituiçōes, nações e abordagens metodológicas.

Edna Apparecida Moura Arcuri

Professora Titular do Departamento de Enfermagem Médico-Cirúrgica 